\title{
APLIKASI PENGENALAN HURUF HIJAIYAH BERBASIS MARKER AUGMENTED REALITY PADA PLATFORM ANDROID
}

\author{
Rusdi Efendi ${ }^{1}$, Endina Putri Purwandari ${ }^{2}$, Muhammad Abdul Aziz ${ }^{3}$ \\ ${ }^{1,2,3}$ Program Studi Teknik Infomatika, Fakultas Teknik, Universitas Bengkulu. \\ Jl. WR. Supratman Kandang Limun Bengkulu 38371A INDONESIA \\ (telp: 0736-341022; fax: 0736-341022) \\ ${ }^{1}$ r_efendi@yahoo.com \\ ${ }^{2}$ endinaputrip@gmail.com \\ ${ }^{3}$ muhammad200893@gmail.com
}

\begin{abstract}
Abstrak: Pada penerapannya Augmented Reality bisa diimplementasikan pada perangkat yang memiliki kamera. Penelitian ini bertujuan untuk membangun suatu aplikasi yang dapat membantu pengguna dalam mengenalkan Huruf Hijaiyah pada smartphone android dengan menerapkan Augmented Reality. Aplikasi ini akan mengakses kamera device untuk mengenali marker Huruf Hijaiyah sehingga ketika marker berhasil dikenali akan menampilkan 3D Huruf Hijaiyah beserta audio pelafalannya. Aplikasi Augmented Reality ini dikembangkan berdasarkan metode Sekuensial Linier dan analisis berorientasi objek Unified Modeling Language (UML). Untuk membangun aplikasi ini menggunakan Vuforia SDK dan Unity3D. Pengujian sistem menunjukkan bahwa (a) Penggunaan smartphone yang berbeda dapat menjalankan aplikasi dengan baik; (b) Jarak optimal yang dibutuhkan untuk dapat mendeteksi marker antara 10-50 cm; (c) Intensitas pencahayaan minimal untuk mendeteksi marker pada 80 lux; (d) Skala ukuran marker yang dibutuhkan dengan ukuran minimal 7,5 x 7,5 cm; (e) Kapasitas tampilan marker yaitu $50 \%$ dari ukuran marker yang digunakan, (f) Sudut deteksi marker yang optimal yaitu sebesar $45^{\circ}$, dan juga pada uji kualitas aplikasi menunjukkan bahwa penilaian aplikasi ini berada pada kategori sangat baik.
\end{abstract}

Kata kunci: Android, Augmented Reality, Huruf Hijaiyah, Marker.

Abstract: On the implementation, Augmented Reality can be implemented on the device that has a camera. This research aims to create an application that can help the users for recognizing of Hijaiyah Letter on android smartphone by implementing the augmented reality. The application will access the device camera to recognize the marker of Hijaiyah Letter, so while the marker has been detect, it will show the 3D Object of Hijaiyah Letter with the audio spelling. This Augmented Reality applications developed by Linear Sequential's method and Unified Modeling Language (UML) object-oriented analysis. This application is built by using Vuforia and Unity3D. Result of test shows that (a) The different use of smartphone can applied for this application; (b) An effective marker detection distances between $10-50 \mathrm{~cm}$; (c) Minimum requires sufficient light intensity for marker detection is $80 \mathrm{lux}$; (d) Minimum requires scale of marker size is 7,5 $\times 7,5 \mathrm{~cm}$; (e)
Capacity of marker view is $50 \%$ of using marker size; ( $f$ ) Optimum edge of marker detection is $45^{\circ}$, and the result test of application quality rating show the best category.

Keywords: Android, Augmented Reality, Huruf Hijaiyah, Marker.

\section{PENDAHULUAN}

Huruf Hijaiyah atau Huruf Arab merupakan huruf yang sudah ada sejak dahulu yang digunakan oleh orang-orang muslim di seluruh penjuru dunia untuk membaca Al-Quran. Jumlah Huruf Hijaiyah yang umumnya diketahui berjumlah 28 huruf,

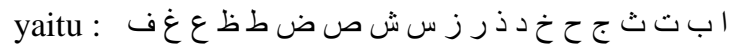
(Musa, 2012). Namun terdapat penambahan huruf yaitu huruf “๕“ dan "y” 
sehingga menjadikan jumlahnya menjadi 30 huruf. Proses pengenalan Huruf Hijaiyah biasanya dilakukan secara manual dengan menggunakan buku Iqra' yang terdapat Huruf Hijaiyah. Pengenalan tersebut dilakukan dengan cara membaca huruf dan melafalkannya sehingga dalam proses pengenalannya masih belum terlalu menarik dan interaktif, khususnya bagi anak-anak yang baru mulai belajar mengaji dan mengenal Huruf Hijaiyah.

Augmented Reality merupakan teknologi yang dapat diterapkan pada aplikasi perangkat mobile Android karena sistem pada Augmented Reality menganalisa secara real-time objek yang ditangkap dalam kamera. Konsep Augmented Reality adalah menggabungkan dunia nyata dan virtual, bersifat interaktif secara real time, dan merupakan animasi 3D. Pada Augmented Reality terdapat dua metode yang digunakan yaitu: marker based tracking dan markerless [2].

Berdasarkan uraian dan permasalahan di atas, penulis tertarik untuk merancang dan membangun aplikasi berbasis android yang dapat digunakan untuk melakukan pengenalan Huruf Hijaiyah. Konsep dari aplikasi ini nantinya selain untuk proses pengenalan Huruf Hijaiyah, ketika dijalankan aplikasi ini akan mengenali Huruf Hijayah berdasarkan pola marker nya, apabila dikenali maka aplikasi ini akan memberikan informasi tambahan berupa 3D, teks dan audio pelafalan dari Huruf Hijaiyah tersebut. Dengan adanya aplikasi ini diharapkan dapat menjadi media yang dapat membantu pengenalan Huruf Hijayah terkhusus bagi anak-anak yang mulai belajar mengaji.

\section{LANDASAN TEORI}

\section{A. Huruf Hijaiyah}

Huruf Hijaiyah atau huruf arab merupakan huruf yang sudah ada sejak dahulu yang digunakan oleh orang-orang muslim di seluruh penjuru dunia untuk membaca Al-Quran. Jumlah Huruf Hijaiyah yang umumnya diketahui berjumlah 28 huruf,

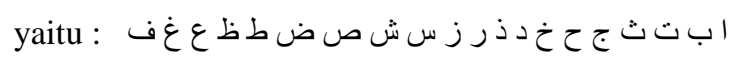
. Namun terdapat penambahan Huruf Hijaiyah yang sering muncul dalam buku Iqra' yaitu huruf “ø” dan “ $\vee$ ” sehingga menjadikan jumlahnya menjadi 30 huruf [1].

\section{B. Augmented Reality}

Augmented Reality merupakan teknologi yang dapat diterapkan pada aplikasi perangkat mobile Android karena sistem pada Augmented Reality menganalisa secara real-time objek yang ditangkap dalam kamera. Konsep Augmented Reality adalah menggabungkan dunia nyata dan virtual, bersifat interaktif secara real time, dan merupakan animasi 3D. Pada Augmented Reality terdapat dua metode yang digunakan yaitu: marker based tracking dan markerless [2].

\section{Android}

Android adalah sebuah sistem operasi untuk perangkat mobile berbasis Linux yang mencakup sistem operasi, middleware dan aplikasi. Android menyediakan platform yang terbuka bagi para pengembang untuk menciptakan aplikasi sendiri. Awalnya, Google Inc. membeli Android Inc. yang merupakan pendatang baru yang membuat piranti lunak untuk ponsel atau smartphone. Kemudian untuk mengembangkan Android, dibentuklah Open Handset Alliance, konsorsium dari 34 perusahaan piranti keras, piranti lunak, dan telekomunikasi, termasuk Google, HTC, Intel, Motorola, Qualcomm, T-Mobile dan Nvidia [3]. 
D. Vuforia $S D K$

Vuforia SDK merupakan software untuk Augmented Reality yang dikembangkan oleh Qualcomm, yang menggunakan sumber yang konsisten mengenai computer vision, yang berfokus pada image recognition. Vuforia mempunyai banyak fitur-fitur dan kemampuan, yang dapat membantu pengembang untuk mewujudkan pemikiran dan ide-idenya tanpa adanya batasan teknikal. Vuforia mendukung para pengembang untuk membuat aplikasi yang dapat digunakan hampir seluruh jenis smartphone dan tablet. Target pada Vuforia merupakan objek pada dunia nyata yang dapat di deteksi oleh kamera, untuk menampilkan objek virtual [4].

\section{E. Metode Pengembangan Sistem}

Model sekuensial linier merupakan salah satu dari metode yang digunakan untuk pengembangan sistem. Sekuensial linier sering disebut juga dengan “siklus kehidupan klasik” atau “model air terjun” (lihat Gambar 1). Model sekuensial linier mengusulkan sebuah pendekatan kepada perkembangan perangkat lunak sistematik dan sekuensial yang mulai pada tingkat dan kemajuan sistem pada seluruh analisis, desain, kode, pengujian dan pemeliharaan [5].

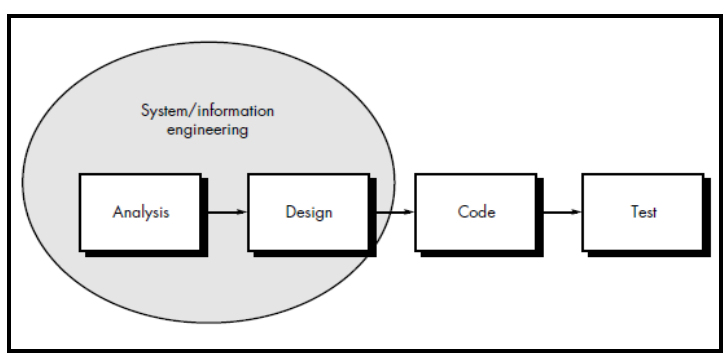

Gambar 1. Model Sekuensial Linier.

\section{Metodologi Penelitian}

A. Metode Pengembangan dan Pengumpulan Data

Metode pengembangan sistem yang digunakan pada penelitian ini yaitu metode sekuensial linear.Adapun teknik pengumpulan data pada penelitian ini adalah:

1. Studi Pustaka

Studi pustaka merupakan metode pengumpulan data yang diperoleh dari bukubuku dan/atau jurnal dalam pencarian referensi terkait pengumpulan data maupun perancangan aplikasi yang akan dibangun, yaitu referensi mengenai Huruf Hijaiyah, Augmented reality, marker Augmented Reality dan Android.

\section{Teknik Sampling}

Pengumpulan data dilakukan dengan menggunakan teknik sampling, yaitu dengan mengambil gambar pola pada modus kamera dari Huruf Hijaiyah. Hal ini dilakukan untuk dapat mengenali Huruf Hijaiyah berdasarkan pola marker yang telah diberikan.

\section{B. Metode Pengujian}

Setiap produk perangkat lunak dapat diuji melalui beberapa pendekatan pengujian, yang pertama disebut sebagai

black-box testing, kedua disebut sebagai white-box testing dan yang ketiga adalah pengujian kualitas aplikasi.

\section{ANALISIS DATA DAN PERANCANGAN}

\section{A. Analisis Permasalahan}

Pengenalan Huruf Hijaiyah biasanya dilakukan secara manual dengan menggunakan buku Iqra' atau media lain yang terdapat Huruf Hijaiyah.

Augmented Reality merupakan teknologi yang menggabungkan interaksi antara dunia nyata dengan dunia maya, pada penerapannya juga dapat digunakan sebagai media pengenalan objek. Oleh karena itu penulis membangun sebuah aplikasi berbasis Augmented Reality yang dapat digunakan untuk melakukan pengenalan Huruf Hijaiyah pada platform Android. 
B. Analisis Antarmuka Pengguna Sistem

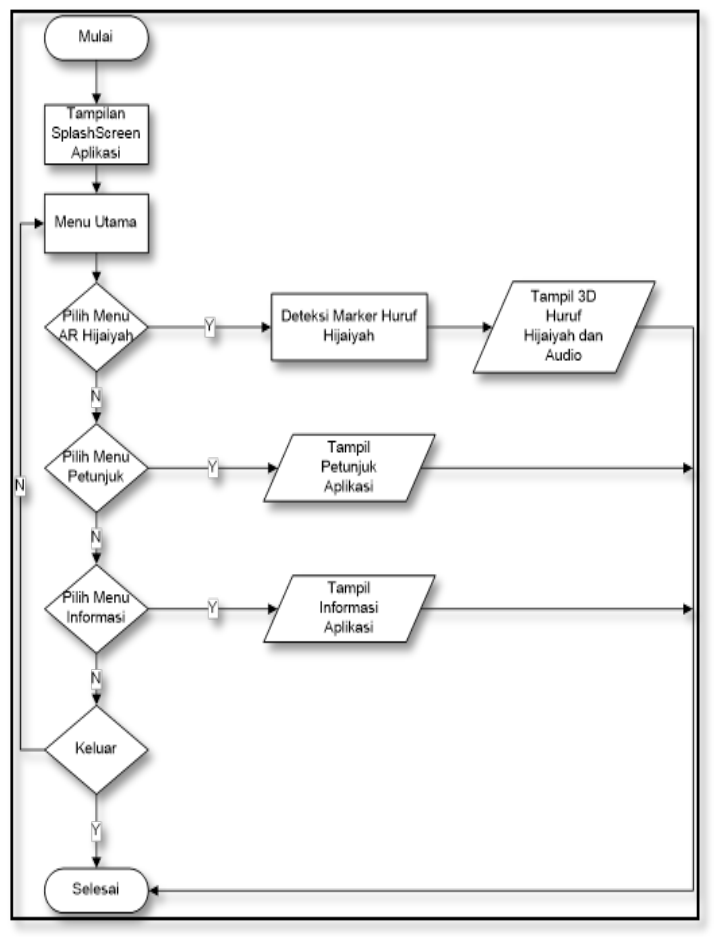

Gambar 2. Diagram Alur Antarmuka Pengguna

Berdasarkan diagram antarmuka pengguna pada Gambar 2, terdapat beberapa menu yang terdapat pada aplikasi yakni menu ARHijaiyah, informasi, petunjuk dan menu keluar aplikasi. Adapun penjelasan dari diagram alur antarmuka pengguna, sebagai berikut:

1. Halaman awal aplikasi, pada halaman awal ini merupakan tampilan splash screen dari aplikasi yang berupa Gambaran tentang aplikasi pengenalan Huruf Hijaiyah.

2. Halaman utama, pada halaman ini menampilkan halaman menu utama dari aplikasi, pada halaman utama ini terdapat beberapa menu yang bisa dipilih oleh pengguna untuk menjalankan aplikasi ini.

3. Menu Belajar Hijaiyah, pada menu ini merupakan pilihan untuk menampilkan Augmented Reality berupa informasi mengenai Huruf Hijaiyah, yaitu teks, audio pengucapan dan 3D dari Huruf Hijaiyah.
4. Menu Petunjuk, pada menu ini merupakan menu untuk menampilan petunjuk penggunaan aplikasi.

5. Menu Informasi, pada menu ini merupakan menu untuk menampilkan informasi dari aplikasi mulai dari pembuat, asal aplikasi dan informasi lainnya terkait aplikasi pengenalan Huruf Hijaiyah ini.

6. Меnu Keluar, pada menu ini merupakan menu untuk keluar dari aplikasi.

\section{Analisis Fungsional Sistem}

Analisis fungsional sistem merupakan tahapan analisis yang dilakukan berdasarkan masukan, proses dan juga keluaran yang dihasilkan dari sistem yang dibangun.

\section{Analisis Non-Fungsional Sistem}

Analisis non-fungsional merupakan paparan mengenai kebutuhan hardware dan software dalam membuat sistem. Adapun kebutuhan dari aplikasi pengenalan Huruf Hijayah berbasis marker Augmented Reality ini adalah:

1. Kebutuhan Perangkat keras (hardware) Perangkat keras yang digunakan dalam penelitian ini adalah : 1 unit laptop dengan spesifikasi setara Intel Core i3$370 \mathrm{M}$ processor $2.4 \mathrm{GHz}$, RAM 3GB DDR3, Keyboard dan mouse dan juga modem.

2. Kebutuhan Perangkat lunak (software) Perangkat lunak yang digunakan dalam penelitian ini adalah : Untuk rancang bangun pembuatan laporan menggunakan Sistem Operasi Windows 7 Ultimate 32 bit, Java Development Kit (JDK) 7, Unity 4.3.2 untuk membangun aplikasi, Vuforia SDK 2.8.7 untuk menerapkan Augmented Reality pada aplikasi, Google SketchUp 2015 untuk membuat 3D Huruf Hijaiyah, 
Photoshop CS3 untuk merancang marker dan Astah Community 6.7 untuk merancang diagram UML dari aplikasi.

\section{E. Perancangan UML (Unifield Modelling Language)}

1. Use Case Diagram

Use case Diagram menggambarkan fungsionalitas yang diharapkan dari sebuah sistem, yaitu bagaimana cara pengguna berinteraksi dengan sistem yang akan dibuat. Sehingga pengguna bisa mengetahui apa saja interaksi yang bisa terjadi. Adapun tampilan use case diagram aplikasi terdapat pada Gambar 3 berikut:

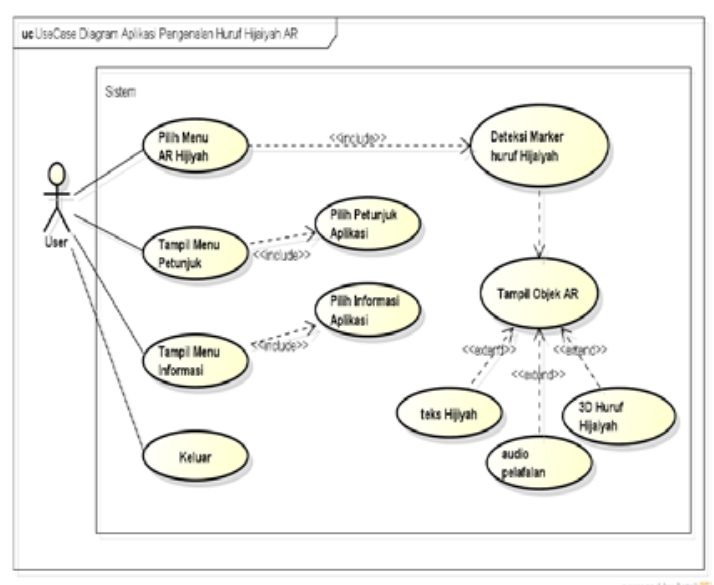

Gambar 3. Use Case Diagram Apikasi

Pada gambar 3 diatas, merupakan gambar Use case diagram dari aplikasi pengenalan Huruf Hijaiyah berbasis Augmented Reality, aktor dalam hal ini bertindak sebagai pengguna melakukan interaksi terhadap sistem. Interaksi yang dilakukan yaitu:

a. Pilih menu AR Hijaiyah dimana pada use case ini terhubung ke use case deteksi marker Huruf Hijaiyah, dan tampil Objek AR.

b. Tampil menu petunjuk

c. Tampil menu informasi, dan

d. Keluar.

\section{Class Diagram}

Class diagram digunakan untuk menggambarkan hubungan antara kelas-kelas dalam model. Pada sebuah aplikasi berorientasi objek, kelas memiliki atribut (variabel anggota), operasi (fungsi anggota) dan hubungan dengan kelas lain. Elemen dasar dari diagram kelas digambarkan sebuah ikon yang mewakili kelas. Adapun tampilan class diagram terdapat pada Gambar 4 berikut:

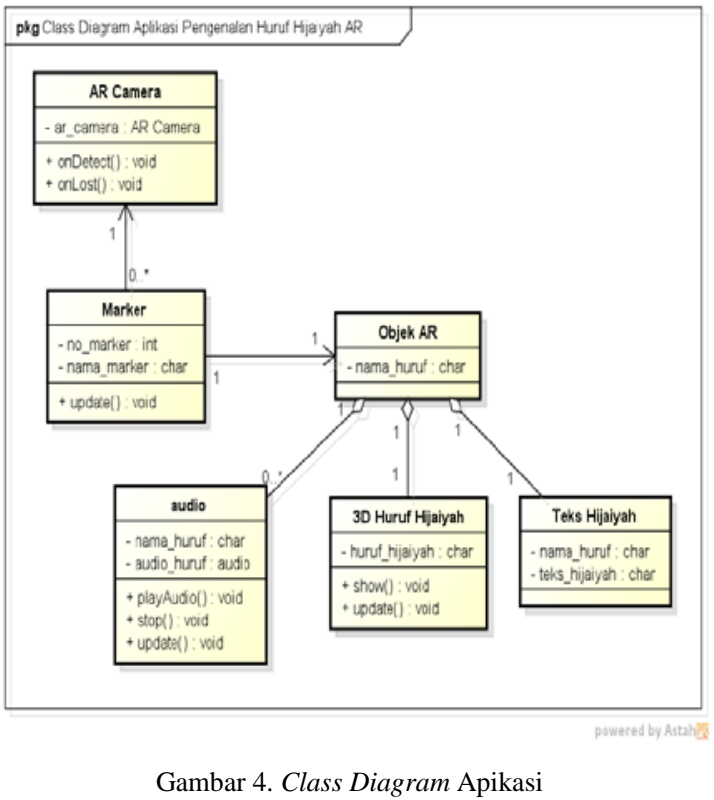

Berdasarkan Gambar 4 diatas, terdapat beberapa kelas yaitu, kelas AR Camera, markerless, audio, objek AR, 3D Huruf Hijiyah dan teks Hijaiyah. Dimana pada setiap kelas memiliki hubungan masing-masing, pada kelas AR camera dan marker saling berasosiasi dan juga pada kelas objek $A R$. Pada kelas audio, 3D Huruf Hijaiyah dan teks Hijaiyah berhubungan generalisasi dikarenakan pada ketiga kelas tersebut merupakan bagian dari kelas objek $A R$ dengan derajat relasi berbeda-beda.

\section{Sequence Diagram}

Pada sequence diagram menggambarkan urutan dari penggunaan aplikasi yang dimulai dari user yang menjalankan aplikasi, sehingga aplikasi 
akan mengaktifkan kamera, kemudian mendeteksi marker. Apabila terdeteksi maka akan dilakukan pencocokan pola, ketika pola cocok maka aplikasi akan menampilkan objek $A R$ kepada user tersebut. Apabila pola dan markerless tidak terdeteksi maka akan kembali ke pengaktifan kamera. Adapun tampilan sequence diagram terdapat pada Gambar 5 berikut:

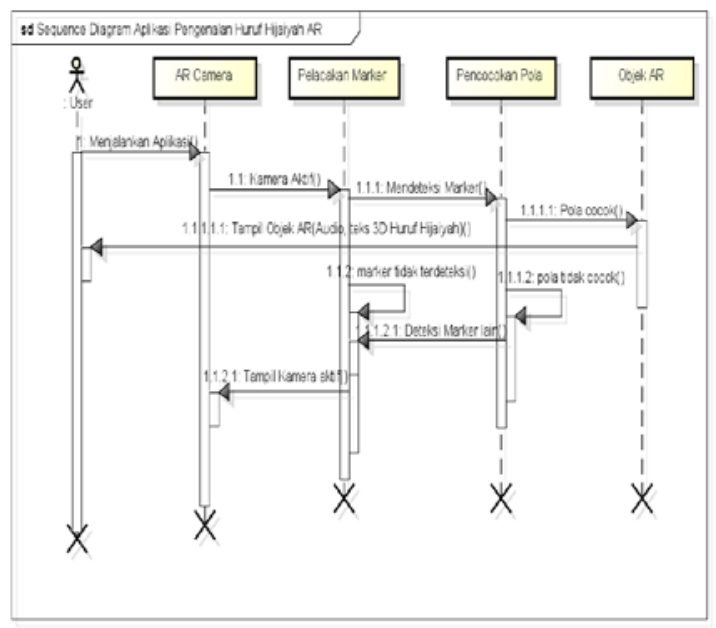

Gambar 5. Sequence Diagram Apikasi

\section{Activity Diagram}

Pada activity diagram aplikasi pengenalan

Huruf Hijaiyah berbasis Augmented Reality penggambaran diagram menunjukkan bagaimana aktifitas yang terjadi ketika pengguna menjalankan aplikasi tersebut. Activity diagram aplikasi pengenalan Huruf Hijaiyah berbasis Augmented Reality dapat dilihat pada Gambar 6 berikut:

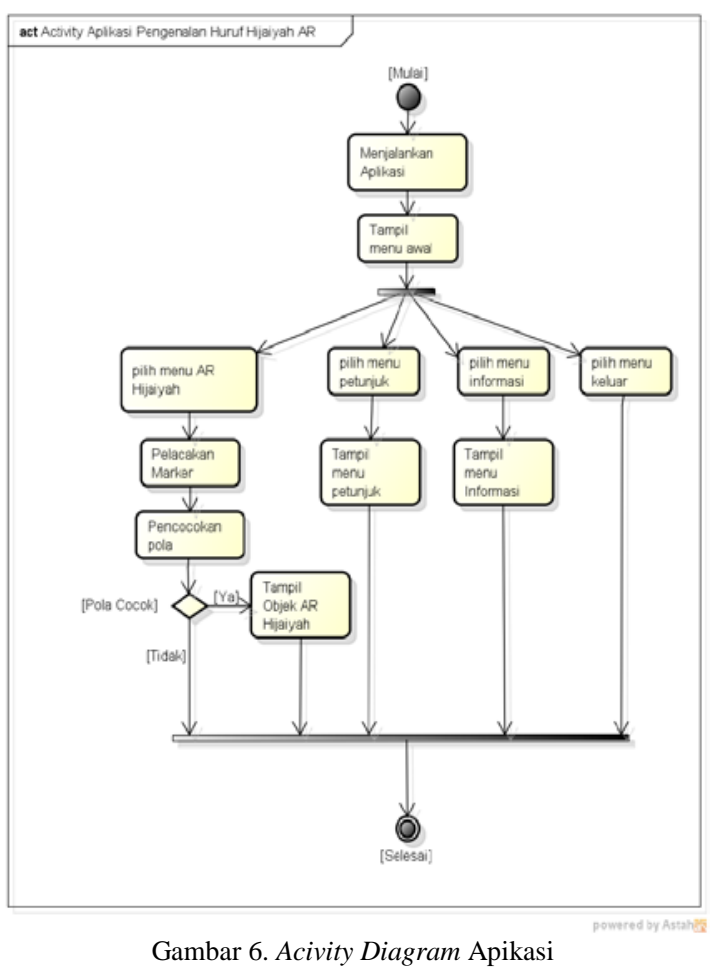

Pada Gambar 6 merupakan tampilan Activity diagram aplikasi pengenalan Huruf Hijaiyah berbasis Augmented Reality penggambaran diagram menunjukkan bagaimana aktifitas yang terjadi ketika pengguna menjalankan aplikasi tersebut.

\section{HASIL DAN PEMBAHASAN}

Setelah dilakukan analisis dan perancangan sistem, selanjutnya yang dilakukan adalah tahap implementasi. Berikut ini adalah hasil implementasi pada sistem:

\section{A. Implementasi Sistem}

Pada tahap ini dilakukan implementasi dan penulisan kode ke dalam bahasa pemrograman sehingga menghasilkan sebuah aplikasi yang sesuai dengan tahap analisis dan perancangan sebelumnya. Aplikasi pengenalan Huruf Hijaiyah berbasis Augmented Reality dibuat menggunakan platform Android. Pada tahap ini hal pertama yang diakukan adalah pembahasan mengenai langkahlangkah pengerjaan Augmented Reality menggunakan platform Android yang dibangun 
dengan software Unity 3D dengan bahasa pemrograman C\# dan juga Java Script, mulai dari pembuatan marker, perancangan 3D Huruf Hijaiyah, dan pembuatan aplikasi pengenalan Huruf Hijaiyah berbasis Augmented Reality.

\section{B. Pengujian Sistem}

Setelah tahap implementasi sistem, tahap selanjutnya yaitu pengujian system. Pengujian yang dilakukan terhadap setiap pengkodean yang terdiri dari white box dan black box. Pengujian white box dilakukan dengan menguji source code yang ada pada aplikasi. Pengujian black box dilakukan untuk menguji apakah sistem yang dikembangkan sesuai dengan spesifikasi fungsional sistem.

1. Tampilan Halaman Awal Aplikasi (Splash Screen)

Halaman awal aplikasi adalah halaman yang pertama kali diakses oleh pengguna ketika menjalankan aplikasi, halaman ini langsung terhubung ke halaman utama aplikasi. Adapun tampilan splash screen dapat dilihat pada Gambar 7 berikut:

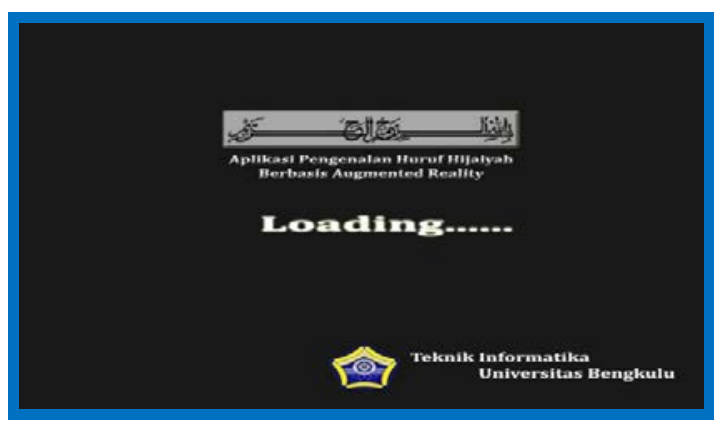

Gambar 7. Tampilan halaman awal aplikasi

\section{Tampilan Halaman Utama Aplikasi}

Halaman utama merupakan halaman yang tampil setelah splash screen aplikasi. Halaman ini menampilkan menu utama dari aplikasi. Pada halaman ini terdapat beberapa menu utama, yaitu menu belajar Hijaiyah, petunjuk, informasi, dan menu keluar aplikasi. Adapun tampilan dari halaman utama aplikasi dapat dilihat pada Gambar 8 berikut:

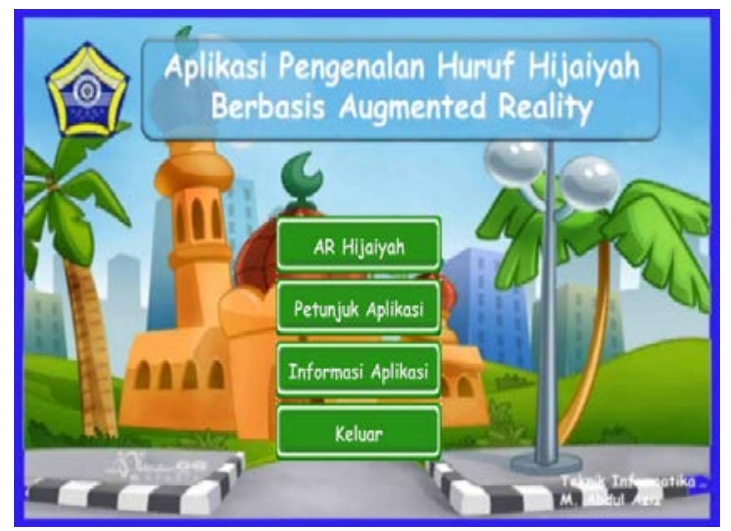

Gambar 8. Tampilan halaman utama aplikasi

3. Tampilan Menu AR HIjaiyah

Menu AR Hijaiyah merupakan pilihan untuk menampilkan proses penganalan Huruf Hijaiyah berbasis Augmented Reality. Ketika pengguna memilih menu AR Hijaiyah maka aplikasi akan mengkatifkan kamera dan menampilkan beberapa pilihan button menu yaitu button kembali, aktifkan flash dan button auto focus. Adapun tampilan dari halaman utama aplikasi dapat dilihat pada Gambar 9 berikut:

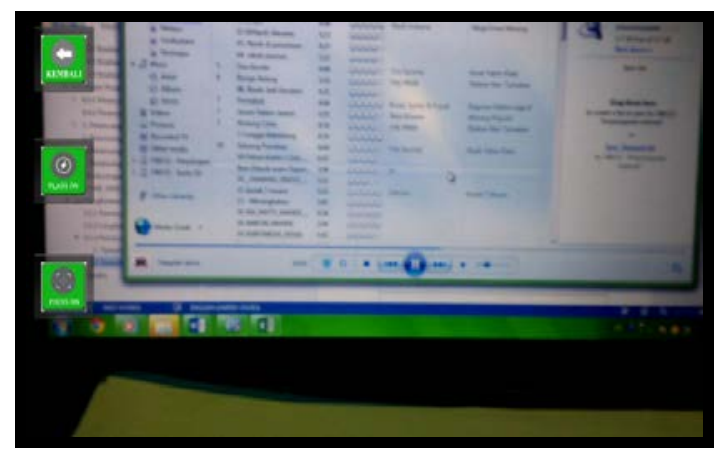

Gambar 9. Tampilan menu AR Hijaiyah aplikasi

\section{Tampilan Menu Petunjuk Aplikasi}

Menu petunjuk aplikasi merupakan menu untuk menampilkan petunjuk bagaimana cara penggunaan aplikasi. Adapun tampilan menu 


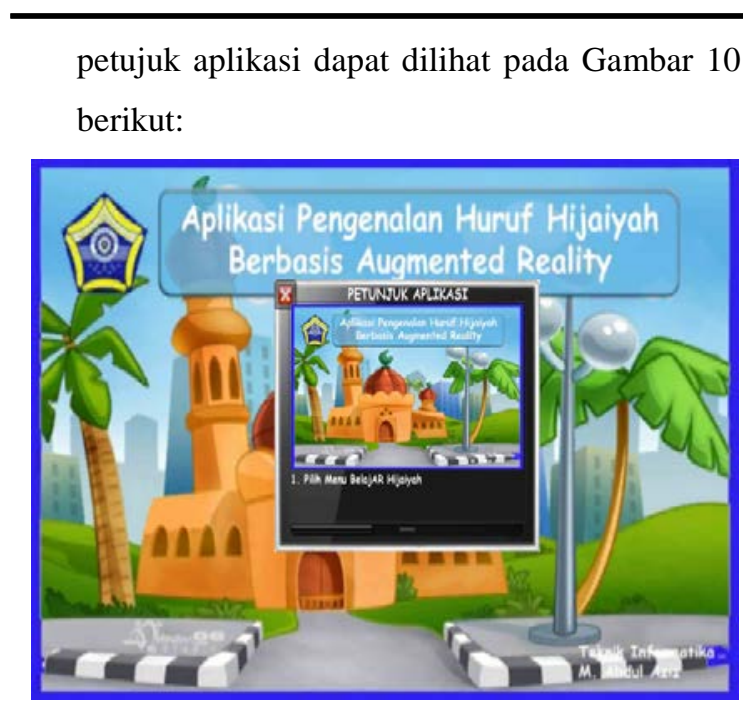

Gambar 10. Tampilan menu petunjuk aplikasi

5. Tampilan Menu Informasi Aplikasi

Menu informasi merupakan menu untuk menampilkan informasi aplikasi. Adapun tampilan menu informasi aplikasi dapat dilihat pada Gambar 11 berikut:

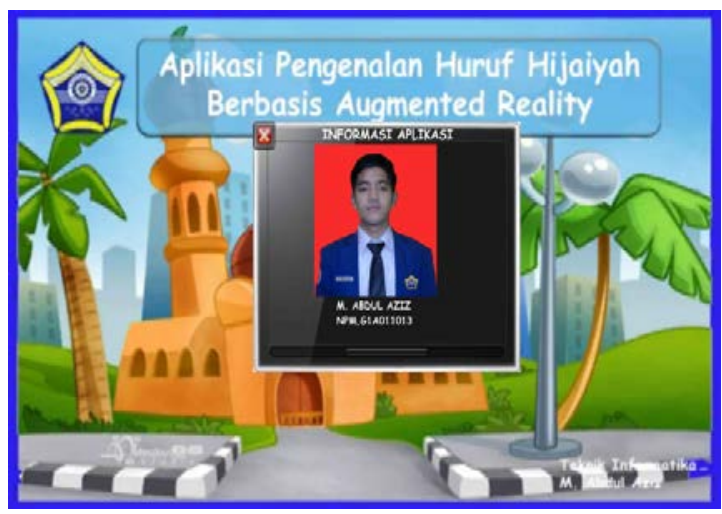

Gambar 11. Tampilan menu informasi aplikasi

C. Pengujian pada Smartphone Android yang Berbeda Jenis

Pada pengujian dengan menggunakan Smartphone Android yang berbeda jenis, dilakukan dengan mengujikan beberapa jenis smartphone yang berbeda, adapun hasil pengujian sebagai berikut:

\section{Asus Zenfone 5}

Spesifikasi : Cpu : Intel Atom $1.6 \mathrm{GHz}$ Dual Core Processor, RAM : 1
GB, Kamera Belakang : 8

MPx, OS : 4.3 Jelly bean.

Hasil Running Aplikasi : Berhasil

Hasil Deteksi marker : Berhasil

Keterangan : Aplikasi Berhasil

dijalankan, fungsi menu dan 3D Objek mampu ditampilkan dengan baik

2. Oppo Joy R1001

Spesifikasi : Cpu : Dual Core Processor $1.3 \mathrm{GHz}, \mathrm{RAM}$ : $512 \mathrm{MB}$, Kamera Belakang : 5 MPx, OS : 4.3 Jelly bean

Hasil Running Aplikasi : Berhasil

Hasil Deteksi marker : Berhasil

Keterangan : Aplikasi berhasil dijalankan, fitur auto focus tidak dapat dijalankan dikarenakan pada kamera smartphone ini tidak didukung fitur auto focus.

\section{Xiaomi Redmi $1 \mathrm{~s}$}

Spesifikasi : Cpu : Quad Core 1.6 GHz Processor, RAM : 1 GB, Kamera Belakang : 8 MPx, OS : 4.3 Jelly bean.

Hasil Running Aplikasi : Berhasil.

Hasil Deteksi marker : Berhasil.

Keterangan : Aplikasi Berhasil dijalankan, fungsi menu dan 3D Objek mampu ditampilkan dengan baik.

\section{Pengujian Terhadap Jarak Deteksi Marker}

Pada pengujian ini diperoleh hasil bahwa untuk dapat mendeteksi marker, jarak optimal yang dianjurkan adalah dari 10 sampai $50 \mathrm{~cm}$, sementara semakin jauh jarak antara marker 
dengan smartphone maka semakin sulit untuk dapat dideteksi yaitu pada jarak 60 sampai $100 \mathrm{~cm}$.

E. Pengujian Terhadap Pengaruh Intensitas Pencahayaan

Pada pengujian tehadap pengaruh intensitas pencahayaan ini, dilakukan untuk mengetahui bagaimana pengaruh intensitas pencahayaan terhadap proses deteksi marker. Untuk menentukan tingkat intensitas pencahayaan digunakan sebuah aplikasi Android yang bernama Light Meter, dimana pada aplikasi ini dapat digunakan untuk mengukur tingkat intensitas pencahayaan dari suatu ruangan ataupun lokasi dengan satuan “lux”. Adapun tingkatan hasil pengukuran tingkat intensitas pencahayaan ketika dilakukan pengujian tersebut dapat dilihat pada Tabel 1 sebagai berikut:

Tabel 1. Hasil Pengukuran Intensitas Pencahayaan

\begin{tabular}{|c|c|c|c|}
\hline No & $\begin{array}{c}\text { Tingkat } \\
\text { Intensitas } \\
\text { Pencahayaan }\end{array}$ & Keterangan & $\begin{array}{c}\text { Kondisi } \\
\text { Lokasi } \\
\text { Pengukuran }\end{array}$ \\
\hline 1 & $2 \operatorname{lux}$ & Very Low & $\begin{array}{l}\text { Di dalam } \\
\text { ruangan tanpa } \\
\text { pencahayaan }\end{array}$ \\
\hline 2 & $6 \operatorname{lux}$ & Very Low & $\begin{array}{l}\text { Di dalam } \\
\text { ruangan tanpa } \\
\text { pencahayaan }\end{array}$ \\
\hline 3 & 10 lux & Low & $\begin{array}{l}\text { Di dalam } \\
\text { ruangan } \\
\text { dengan } \\
\text { sedikit } \\
\text { pencahayaan }\end{array}$ \\
\hline 4 & $23 \operatorname{lux}$ & Low & $\begin{array}{l}\text { Di dalam } \\
\text { ruangan } \\
\text { dengan } \\
\text { sedikit } \\
\text { pencahayaan }\end{array}$ \\
\hline 5 & 80 lux & $\begin{array}{l}\text { Illuminated } \\
\text { Accepted }\end{array}$ & $\begin{array}{l}\text { Di dalam } \\
\text { ruangan } \\
\text { dengan } \\
\text { pencahayaan } \\
\text { lampu }\end{array}$ \\
\hline 6 & 1020 lux & Very High & $\begin{array}{l}\text { Di luar } \\
\text { ruangan } \\
\text { dengan } \\
\text { sedikit } \\
\text { pencahayaan }\end{array}$ \\
\hline
\end{tabular}

\begin{tabular}{|l|l|l|l|}
\hline 7 & 2092 lux & Sunlight & $\begin{array}{l}\text { Di luar } \\
\text { ruangan } \\
\text { dengan } \\
\text { cahaya } \\
\text { matahari } \\
\text { langsung }\end{array}$ \\
\hline 8 & 3000 lux & Sunlight & $\begin{array}{l}\text { Di luar } \\
\text { ruangan } \\
\text { dengan } \\
\text { cahaya } \\
\text { matahari } \\
\text { langsung }\end{array}$ \\
\hline
\end{tabular}

Pada pengujian ini didapatkan hasil, bahwa intensitas pencahayaan sangat mempengaruhi keberhasilan deteksi marker semakin tinggi tingkat intensitas pencahayaan maka akan semakin baik dalam proses deteksinya adapun ukuran intensitas minimal yaitu 80 lux, sedangkan pada intensitas rendah antara 2 sampai 23 lux marker tidak dapat dideteksi.

\section{F. Pengujian Terhadap Skala Marker}

Pada pengujian ini, jarak deteksi ditentukan dengan ketetapan yang sama, yaitu sejauh $30 \mathrm{~cm}$ dari jarak marker yang dideteksi. Adapun skala ukuran yang diujikan adalah:

1. Ukuran $5 \times 5 \mathrm{~cm}$

2. Ukuran $7,5 \times 7,5 \mathrm{~cm}$

3. Ukuran $10 \times 10 \mathrm{~cm}$

4. Ukuran $15 \times 15 \mathrm{~cm}$

5. Ukuran $20 \times 20 \mathrm{~cm}$

Berdasarkan lima skala ukuran marker yang berbeda dilakukan pengujian sehingga diketahui ukuran optimal yang diperoleh untuk mendeteksi suatu marker. Pada pengujian ini diperoleh hasil bahwa untuk dapat mendeteksi marker, ukuran minimal dari marker yang dianjurkan adalah dari 7,5 x 7,5 cm, sementara semakin kecil ukuran marker maka semakin sulit untuk dapat dideteksi. 
G. Pengujian Terhadap Kapasitas Tampilan Marker

Pada proses pengujian terhadap kapasitas tampilan marker dilakukan proses pengenalan marker untuk mengetahui berapakah kapasitas tampilan marker optimal yang dibutuhkan untuk menampilkan objek 3D Augmented Reality apabila marker tersebut ditutup berdasarkan persentase kapasitas tampilannya. Pada pengujian ini, jarak deteksi ditentukan dengan ketetapan yang sama, yaitu sejauh $30 \mathrm{~cm}$ dari jarak marker yang dideteksi. Dengan ketentuan kapasitas tampilan marker yang diberikan adalah:

1. Kapasitas tampilan $100 \%$

2. Kapasitas tampilan $75 \%$

3. Kapasitas tampilan $50 \%$

4. Kapasitas tampilan $25 \%$

5. Kapasitas tampilan $0 \%$ atau tertutup keseluruhan.

Pada pengujian ini diperoleh hasil bahwa untuk dapat mendeteksi marker, ukuran kapasitas tampilan minimal dari marker yang dibutuhkan adalah 50 \% dari tampilan marker, sementara semakin banyak bagian dari marker yang tertutup maka semakin sulit untuk dapat dideteksi dan menampilkan 3D objek Augmented Reality.

\section{H. Pengujian Terhadap Sudut Deteksi Marker}

Pada proses pengujian terhadap sudut deteksi marker dilakukan proses pengenalan marker untuk mengetahui berapakah posisi sudut optimal dari kamera smartphone ketika diarahkan untuk mendeteksi marker yang dibutuhkan untuk menampilkan objek 3D Augmented. Pada pengujian ini, jarak deteksi ditentukan dengan ketetapan yang sama, yaitu sejauh $20 \mathrm{~cm}$ dari jarak marker yang dideteksi. Dengan ketentuan besar sudut kamera yang diberikan adalah:

1. Sudut $30^{\circ}$
2. Sudut $45^{\circ}$

3. Sudut $60^{\circ}$

4. Sudut $90^{\circ}$ (Kamera smartphone tegak lurus diatas marker)

Pada pengujian ini diperoleh hasil bahwa untuk dapat mendeteksi marker, besar sudut yang dibutuhkan untuk kamera smartphone terhadap marker adalah minimal $45^{\circ}$, sementara semakin tajam sudut yang dibentuk dari marker maka semakin sulit untuk dapat dideteksi dan kurang baik dalam menampilkan 3D objek augmented reality.

\section{Pengujian Kualitas Aplikasi}

Pada pengujian kualitas aplikasi dilakukan untuk mengetahui bagaimana tingkat kualitas aplikasi yang akan digunakan. Pengujian ini dilakukan pada Taman Kanak-Kanak RA As Shaffah, dan PAUD IT Auladuna kota Bengkulu. Responden dari uji kelayakan ini dibagi menjadi dua, yaitu;

1. Responden pengguna aplikasi yang berjumlah 50 orang yang terdiri dari 6 orang Guru RA As Shaffah, dan 2 orang Guru PAUD IT Auladuna dan sebanyak 42 orang pengguna umum.

2. Responden pengguna sebagai sasaran uji aplikasi yaitu murid-murid dari RA As Shaffah, dan PAUD IT Auladuna yang berjumlah 74 anak.

Berdasarkan hasil pengujian kualitas aplikasi, dengan memberikan angket berupa pertanyaan terkait kualitas aplikasi (variabel tampilan, kemudahan pengguna, dan kinerja sistem) dan angket motivasi pengaruh anak terhadap penggunaan aplikasi didapatkan hasil bahwa Aplikasi Pengenalan Huruf Hijaiyah berbasis Augmented Reality berada pada kategori “Sangat Baik”. 

VI. PENUTUP
Berdasarkan hasil penelitian, pengujian,
implementasi serta pembahasan pada Rancang
Bangun Aplikasi Pengenalan Huruf Hijaiyah
Berbasis Marker Augmented Reality pada Platform
Andorid, maka didapatkan kesimpulan sebagai
berikut:

1. Penelitian ini telah menghasilkan aplikasi pengenalan Huruf Hijaiyah berbasis marker Augmented Reality dengan pemodelan UML (Unified Modeling Languange) dan bahasa pemrograman JavaScript dan C\#, yang dapat digunakan sebagai media untuk mengenalkan Huruf Hijaiyah.

2. Pada tahapan pengujian dilakukan dengan beberapa tahap kegiatan, yaitu:

a. Pengujian dengan menggunakan smartphone berbeda, aplikasi ini dapat digunakan pada berbagai jenis smartphone android berdasarkan spesifikasinya masing-masing.

b. Pengujian dengan menggunakan jarak deteksi marker, adapun jarak antara smartphone dan marker memiliki jarak optimal untuk deteksi yaitu antara 10-50 $\mathrm{cm}$.

c. Pengujian dengan pengaruh intensitas pencahayaan, dimana intensitas pencahayaan minimal yang dibutuhkan untuk deteksi marker yaitu sebesar 80 lux.

d. Pengujian dengan skala ukuran marker, diperoleh hasil bahwa ukuran marker minimal yang digunakan adalah 7,5 x 7,5 cm.

e. Pengujian terhadap kapasitas tampilan marker, yaitu tampilan minimal dari marker sebesar 50 \% bagian yang terlihat.

f. Pengujian terhadap sudut deteksi marker diperoleh sudutoptimal dari kamera smartphone terhadap marker yaitu sebesar $45^{\circ}$, namun untuk menampilkan 3d secara baik sudut yang optinal yaitu sebesar $90^{\circ}$.

3. Pada pengujian kualitas aplikasi, berdasarkan hasil penilaian angket menunjukkan bahwa aplikasi pengenalan Huruf Hijaiyah berbasis marker Augmented Reality berada pada ketegori "Sangat Baik".

Berdasarkan pada hasil penelitian, pembahasan serta pengujian terhadap aplikasi ini, untuk pengembangan yang akan datang penulis menyarankan sebagai berikut:

1. Pengembangan aplikasi ini kiranya dapat dikembangkan pada platform lainnya, seperti iphone dan blackberry. Sehingga aplikasi ini dapat diakses dan digunakan oleh semua user.

2. Aplikasi pengenalan Huruf Hijaiyah berbasis marker Augmented Reality ini kedepannya bisa dikembangkan lebih lanjut untuk pengenalan perkata.

3. Pada proses pengenalannya diharapkan aplikasi ini dapat mengenali Huruf Hijaiyah secara otomatis dan menjadi lebih baik, sehingga tidak perlu mencetak marker Huruf Hijaiyah yang terbatas pada marker yang sudah didaftarkan pada aplikasi.

\section{REFERENSI}

[1] Musa, A. I. (2012). AL DAN HURUF HIJAIYAH. Dipetik December Minggu, 2014, dari Pesantren Ulil Albab: http://www.ulilalbab.wen.ru

[2] T.Azuma, R. (1997). A Survey of Augmented Reality in Presences : Teleoperators and Virtual Environtments

[3] Safaat, N. (2012). Pemrograman Aplikasi Mobile Smartphone dan Tablet PC Berbasis Android. Bandung: Informatika.

[4] Mario Fernando, S. M. (2013). Membuat Aplikasi Android Augmented Reality Menggunakan Vuforia SDK dan Unity. Manado: Buku AR Online, Dhika Prihantono.

[5] Pressman, R. S. (2001). Software Engineering a Practitioner's Approach (5th Edition). New York: McGraw-Hill Company. 